R OCZNIKI HUMANIST Y CZNE

Tom LXIX, zeszyt $5-2021$

ZESZYT SPECJALNY / SPECIALE UITGAVE

DOI: http://doi.org/10.18290/rh21695sp-5

MURIEL WATERLOT

\title{
VERTALEN IN HET VREEMDETALENONDERWIJS: WIKIPEDIA ALS DIDACTISCH HULPMIDDEL?
}

\begin{abstract}
Dit artikel betreft de didactiek van het vreemdetalenonderwijs (hierna afgekort 'vto') en presenteert de resultaten van een vooronderzoek dat verricht werd om na te gaan in hoeverre Wikipedia als didactisch hulp- en leermiddel kan worden ingezet in de vertaalcolleges van de masteropleiding neerlandistiek aan de Johannes Paulus II Katholieke Universiteit van Lublin ${ }^{1}$. Met het oog op de vrije toegang van deze online encyclopedie en de rijkdom aan teksten (in het Pools en het Nederlands) met een culturele inhoud die Wikipedia aanbiedt, onderzochten we in hoeverre Wikipedia-vertaling ingezet kan worden in vertaalcolleges in het vreemdetalenonderwijs (hierna: vto-vertaalcolleges) om de talige en niet-talige competenties van de Poolse taalleerders te bevorderen.

Het toenemende belang van technologische hulpmiddelen (zoals elektronische woordenboeken, terminologische databanken en software voor automatische vertaling) die vertaling ondersteunen en het gebruik ervan in het taalonderwijs enerzijds, en het feit dat Poolse afgestudeerden in de neerlandistiek vaak als vertaler aan de slag gaan anderzijds, vormden de aanzet voor dit onderzoek dat werd verricht als voorfase (casestudie) van een uitgebreidere studie naar de praktische toepassing van Wikipedia-vertaalactiviteiten in taalverwervingscolleges.
\end{abstract}

Trefwoorden: T2-vertaling; vreemdetaalonderwijs (vto); vertaaldidactiek; Wikipedia; vertaalvaardigheid; communicatieve competentie; interculturele competentie.

Dr hab. Muriel Waterlot is universitair hoofddocent taalkunde en vertaalkunde bij de leerstoel Nederlandse Taalkunde, Faculteit Humane Wetenschappen van de Johannes Paulus II Katholieke Universiteit van Lublin. Haar onderzoeksterrein is met name de vertaaldidactiek in het vreemdetalenonderwijs; correspondentieadres: Katedra Literatury i Języka Niderlandzkiego IFA, Katolicki Uniwersytet Lubelski Jana Pawła II, al. Racławickie 14, 20-950 Lublin; e-mail: murielwaterlot@kul.pl; ORCID: https://orcid.org/0000-0002-1665-2543.

${ }^{1}$ De opleiding neerlandistiek aan Johannes Paulus II Katholieke Universiteit van Lublin (Polen) biedt T1- en T2-vertaalcolleges aan in het kader van praktische taalvaardigheidscolleges (zowel in de master- als in de bacheloropleiding). In dit artikel zullen we voor dit soort colleges de term 'vto-vertaalcolleges' hanteren. 


\section{INLEIDING}

Aan het eind van de negentiende eeuw, met de komst van de directe methode (Direct Method) of natuurlijke methode (Natural Method), werd vertalen in de taalles verboden (Howatt 192). Door de tegenstanders van de grammatica-vertaalmethode werd het namelijk als contraproductief beschouwd in het taalverwervingsproces, vooral voor de ontwikkeling van de spreekvaardigheid. Onder invloed van de internationalisering van de maatschappij en de groeiende belangstellling voor de interculturele communicatieve dimensie in het vreemdetalenonderwijs (hierna: vto), wordt vertalen sinds medio 1990 geherwaardeerd, en sinds 2001 door het Gemeenschappelijk Europees Referentiekader (afgekort ERK) zelfs opnieuw geïntroduceerd onder de benaming 'bemiddeling'. Onder dit soort activiteiten rekent het ERK vertalen en tolken (ERK 2008, 147). Dit betekent dat het onderzoek rond vertalen als werkmethode zich tegenwoordig niet langer concentreert op de doeltreffendheid ervan in het vto, maar op de manier waarop het toegepast kan worden in taalverwervingslessen.

In het boek Functionele en taakgerichte vertaaldidactiek in het universitaire vreemdetalenonderwijs (Waterlot) wijzen we onder meer op de mogelijkheid die de vreemdetaaldocent heeft om in een vertaalles in het vto te opteren voor een taakgerichte, functionele aanpak. In de praktijk komt dit erop neer dat de taalleerder bijvoorbeeld bij de te vertalen tekst een vertaalopdracht krijgt die hem - voordat hij begint te vertalen - moet aanzetten tot reflectie over de doelgroep en doelcultuur waarin zijn vertaling zal 'functioneren'. Op die manier wordt hij zich ervan bewust dat vertalen een vorm van interculturele communicatie is, waarbij de weergave van het functionele doel (informeren, verzoeken etc.) van de tekst in de doeltaal en cultuur centraal staat, en niet de letterlijke weergave van de inhoud van de brontekst. In het geval van Wikipedia-vertalingen is een vertaalopdracht overbodig. De taalleerder weet waar zijn vertaling terecht zal komen en dat die door een ruim en gevarieerd publiek gelezen zal worden. Dit zal hem er des te meer toe aanzetten om rekening te houden met een heldere informatieoverdracht voor de lezers van de doelcultuur.

Omdat Wikipedia thans wordt gebruikt in vertalersopleidingen, besloten we om in de voorfase van deze casestudie het potentiële nut en de potentiële voordelen van Wikipedia-vertaalactiviteiten in het vto te bepalen op basis van literatuuronderzoek in het domein van de didactiek van de vertalersopleiding. Hierbij gingen we op zoek naar informatie over 1) de leereffecten (in termen van competenties) die in vertalersopleidingen met Wikipedia- 
activiteiten bereikt kunnen worden en 2) de didactische voor- en nadelen van Wikipedia als didactisch hulpmiddel in vertaalcursussen.

De structuur van dit artikel ziet er als volgt uit: in de eerste paragraaf wordt de betekenis van de term Wikipedia verklaard en wordt het ontstaan en de doelstelling van Wikipedia bondig toegelicht. Vervolgens worden in paragraaf 2 de oorzaken in de veranderingen in de houding van academici jegens het gebruik van Wikipedia toegelicht en de toepassing en waardering van Wikipedia-activiteiten in vertalersopleidingen onderzocht. Daarna worden in paragraaf 3 de onderzoeksvragen en -methode gepresenteerd. In paragraaf 4 en 5 worden de onderzoeksresultaten gerapporteerd en besproken. Het artikel wordt afgerond met een conclusie over het nut en de voor- (en na) delen van Wikipedia voor vto-vertaallessen.

\section{WIKIPEDIA: BETEKENIS, IMPACT EN DOELSTELLING}

De naam Wikipedia is een samentrekking van wiki dat in het Hawaiiaans snel betekent, en het Engelse woord encyclopedia. Wikipedia is een online encyclopedie die volledig gratis wordt aangeboden en waar gebruikers informatie kunnen aanmaken, wijzigen en verwijderen. Wikipedia streeft ernaar inhoud aan te bieden die vrij herbruikbaar, objectief en verifieerbaar is. Wikipedia behoort tot de top vijf van meest bezochte webdiensten en trekt elke maand ongeveer 500 miljoen bezoekers. Sinds de oprichting in januari 2001 zijn er zo'n 300 verschillende taalversies ontwikkeld, waarbij de oorspronkelijke Engelstalige versie met meer dan 5,6 miljoen artikelen de grootste is gebleven (Kodura 195).

De Nederlandstalige versie startte op 19 juni 2001. Iedereen kan op Wikipedia direct online inhoud publiceren, wijzigen of verwijderen, met inachtneming van de basisregels zoals die met betrekking tot de neutraliteit van de inhoud. Het aanmaken en vertalen van inhoud kan worden uitgeprobeerd in een zogenaamde 'Wikipedia-Zandbak' (zie figuur 1).

In 2010 introduceerde Wikipedia het Wikipedia Education Program (WikiEdu) om de academische gemeenschap aan te moedigen de elektronische encyclopedie uit te breiden. Het idee achter het Wikipedia Education Program is eenvoudig: docenten en studenten worden aangemoedigd om vrije kennis te delen door bij te dragen aan Wikipedia- en Wikimediaprojecten in een academische omgeving, om zo de kwaliteit van de kennis die door deze bron wordt geleverd te helpen verbeteren. 


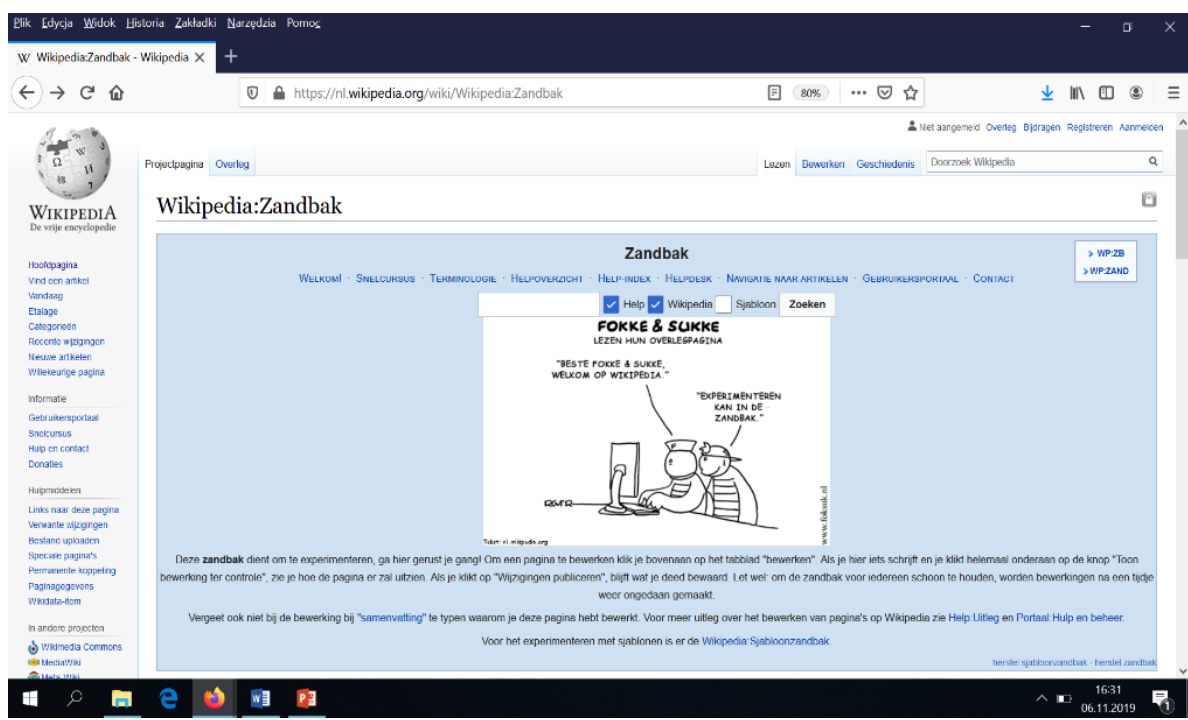

Figuur 1: Wikipedia-Zandbak (uit: nl.wikipedia.org/wiki/Wikipedia:Zandbak/hoofding).
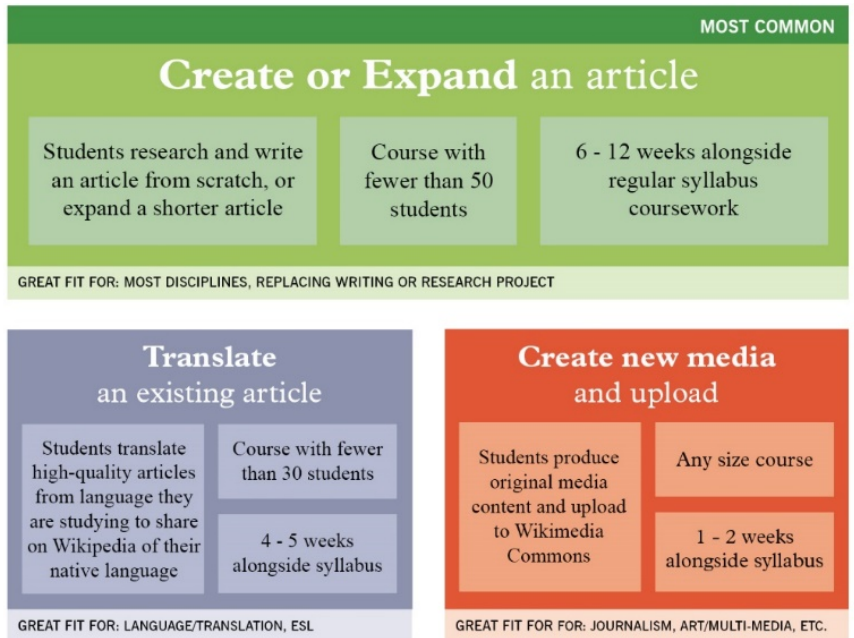

Figuur 2: Overzicht van de mogelijke opdrachten op WikiEdu (uit: wikiedu.org/teach-with-wikipedia/).

Deze activiteiten kunnen de vorm aannemen van het aanmaken van inhoud, het verbeteren en vertalen van bestaande inhoud/teksten, en het aanmaken van mediabestanden voor het platform Wikimedia Commons wat vooral van toepassing is voor studenten die een opleiding volgen in de nieuwe media en journalistiek (zie figuur 2). 
Het platform Wiki Education (wikiedu.org/) biedt een uitgebreide virtuele leeromgeving en tevens hulpmiddelen die docenten en studenten helpen om projecten te starten, in de vorm van tutorials, startgidsen en casestudies. De cursussen die met Wikipedia worden gegeven, maken gebruik van een platform voor het monitoren en beheren van de activiteiten van de studenten, het zogenaamde Dashboard, waar de docent bijvoorbeeld deadlines, opdrachten, verkeersstatistieken en de bewerking van artikelen kan controleren. Deze leer- en werkomgeving wordt in het bijzonder aanbevolen vanwege de betrokkenheid van studenten bij het bewerken en vertalen van artikelen. Hun motivatie om bewerkings- of vertaalopdrachten uit te voeren berust op het feit dat hun werk gezien zal worden door duizenden lezers van Wikipedia. Doordat dit als een begeleide activiteit in een gecontroleerde omgeving geschiedt, komt de kwaliteit van de vertaling en bewerking van Wikipediaartikelen niet in het gedrang (Szymczak).

\section{VERANDERING IN DE HOUDING VAN ACADEMICI JEGENS WIKIPEDIA}

De laatste decennia zijn we getuige van een verandering in de houding van academici jegens Wikipedia. Vroeger was Wikipedia synoniem aan een bron van kennis van lage kwaliteit, met 'plagiaat' en onbetrouwbaarheid', of aan iets wat onwaardig was om in de academische wereld te worden genoemd of gebruikt. Elk spoor van de aanwezigheid van gegevens uit de Wikipedia-encyclopedie in opdrachten of onderzoek van studenten leidde vaak tot een negatieve beoordeling. Vandaag hebben academici hun benadering veranderd. Enerzijds is dit het gevolg van de impact van Wikipedia: met 500 miljoen bezoekers per maand en artikelen in 300 verschillende talen, groeide Wikipedia uit tot een van de grootste en meest herkenbare referentiebronnen van de huidige tijd (Dowell \& Bridges in Kodura). Anderzijds zijn academici en docenten gaan inzien dat Wikipedia gebruikers in staat stelt om kennis te delen en te creëren op dezelfde manier als bijvoorbeeld Facebook, Instagram of You Tube (clips) waar kennis en informatie kan worden overdragen. Langzamerhand zijn didactici gaan inzien dat die aspecten van actieve deelname en online samenwerken aantrekkelijk kunnen zijn voor docenten die het gebruik van Wikipedia in hun colleges overwegen als een open, gratis educatief hulpmiddel dat wereldwijd beschikbaar is voor studenten. 
Als gevolg hiervan zoeken academici tegenwoordig naar manieren om de enorme mogelijkheden die Wikipedia biedt als leermiddel te gebruiken, en ze niet langer te zien als een obstakel voor een goede kennisverwerving. In vertaalopleidingen op universitair niveau wordt Wikipedia bij wijze van voorbeeld tegenwoordig toegepast als hulpmiddel ter ondersteuning van experimentele vertaalactiviteiten met verschillende groepen studenten. Over dergelijke vertaalcursussen met Wikipedia-activiteiten - en hiermee bedoelen we de vertaling van Wikipedia-pagina's - vinden we informatie met betrekking tot talen zoals het Arabisch (Al-Shehari), Spaans (Calzada \& Navarro) en het Pools (Szymczak; Kodura), of met betrekking tot meerdere talen (Alonso \& Calvo). Er bestaan ook internationale Wikipedia-vertaalprojecten. Een uitgebreide lijst hiervan is beschikbaar op Wikimedia UK. Voor zover kon worden onderzocht, werd in de Lage Landen of met Nederlands geen onderzoek verricht naar Wikipedia-activiteiten in vertalersopleidingen.

\section{ONDERZOEKSVRAGEN EN METHODE}

Zoals reeds in de inleiding werd vermeld, maakt dit onderzoek deel uit van de voorfase van een praktische casestudie die de doeltreffendheid van Wikipedia-vertaalopdrachten in het vto in de masteropleiding neerlandstiek in Lublin (Polen) beoogt te evalueren. Doordat Wikipedia tegenwoordig succesvol in vertaalcursussen op universitair niveau wordt toegepast (zie bijv. Szymczak, 2013 en Kodura, 2009), besloten we eerst te onderzoeken welke competenties er in vertalersopleidingen met Wikipedia-activiteiten bevorderd worden, om vervolgens na te gaan of deze overeenkomen met de competenties die in het vto als leerdoel vooropgesteld worden. Bijgevolg luiden de onderzoeksvragen als volgt:

1. Welke competenties worden in het vreemdetaalonderwijs als leerdoel vooropgesteld?

2. Welke competenties worden in vertalersopleidingen met Wikipediaactiviteiten bevorderd?

3. Is er sprake van overeenkomsten met de competenties die met Wikipedia-activiteiten in vertalersopleidingen worden bevorderd en die welke in het vto centraal staan?

Om niet alleen inzicht te krijgen in het nut van Wikipedia in termen van leereffecten (bevordering van competenties), maar ook in de voor- en 
nadelen van de tool, zullen we een vierde onderzoeksvraag beantwoorden die als volgt luidt:

4. Wat zijn de (didactische) voor- en nadelen van het werken met Wikipedia en Wikipedia-vertalingen in vertaallessen?

Wat de methodologie betreft zullen we deze vragen beantwoorden aan de hand van een literatuuronderzoek.

\section{WIKIPEDIA IN VERTAALOPLEIDINGEN EN DE BEVORDERING VAN COMPETENTIES VOOR HET VTO}

Om de eerste onderzoeksvraag met betrekking tot de competenties die in Wikipedia-activiteiten in vertalersopleidingen worden bevorderd te beantwoorden, zullen we eerst stilstaan bij de competenties die van belang zijn in het vto. Op die manier kunnen we naderhand analyseren of er overeenkomsten zijn.

Het Europees Referentiekader (2008) stelt de bevordering van twee competenties $^{2}$ centraal in het taal- en vreemdetalenonderwijs, namelijk de communicatieve competentie en de interculturele competentie. De interculturele competentie wordt door het ERK in verband gebracht met zogenaamde niet-talige competenties of met "het bewustzijn van de verhouding tussen de thuis- en de doelcultuur" (ERK 2008, 97). De communicatieve competentie wordt op haar beurt gerelateerd aan "specifiek talige aspecten" of talige competenties (ERK 2008, 13). Ze bestaat uit drie componenten: de pragmatische, de sociolinguïstische en de linguïstische competenties (ERK 2008, 101).

Om onderzoeksvraag 2 te beantwoorden (betreffende de competenties die in het vertaalonderwijs worden bevorderd met Wikipedia-vertalen en vertalingen) zullen we gebruikmaken van het EMT-model van de Europese Commissie. ${ }^{3}$ Het model, dat vaak wordt gebruikt door onderzoekers, bestaat

\footnotetext{
${ }^{2}$ Het ERK definieert competenties als volgt: "Competenties zijn het totaal aan kennis, vaardigheden en eigenschappen die een mens in staat stellen handelingen uit te voeren." (ERK 2008, 13).

${ }^{3}$ De Europese masteropleiding vertalen (European Master's in Translation) is een partnerschapsproject tussen het directoraat-generaal Vertaling (DGT) van de Europese Commissie en een aantal universiteiten uit een groot aantal Europese landen. EMT is een kwaliteitslabel voor vertaalopleidingen die een masterdiploma aanbieden. Het DGT kent het label toe aan programma's in het hoger onderwijs die voldoen aan de EMT-kwaliteitsnormen voor de opleiding van vertalers. Masteropleidingen die aan deze normen voldoen, kunnen lid worden van het EMT-
} 
uit vijf subcompetenties: (1) language and culture, (2) translation, (3) technology, (4) personal and interpersonal competence en (5) services provision (zie figuur 3). Het stelt een goed georganiseerde machine voor waarin alle tandwielen noodzakelijk zijn opdat de machine goed werkt.

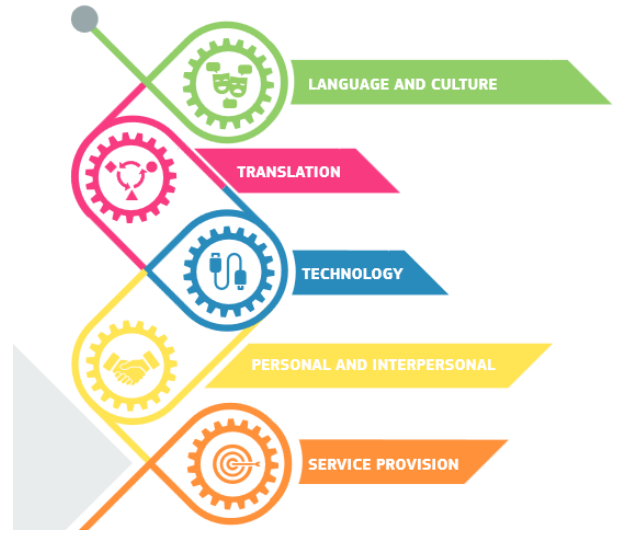

Figuur 3: EMT-model

(uit: ec.europa.eu/info/sites/info/files/emt_competence_fwk_2017_en_web.pdf).

Wanneer we de competenties die centraal staan in vertalersopleidingen vergelijken met die voor het vto in het ERK (2008), kunnen we op basis van het EMT-model constateren dat in dit soort opleidingen talige én niet-talige competenties een cruciale rol spelen. Voor de doeleinden van dit onderzoek zullen we ons in wat volgt dus vooral concentreren op de bevindingen van het onderzoek in de vertaaldidactiek waar sprake is van de meerwaarde van Wikipedia-vertalen en -vertalingen voor de bevordering van talige en niettalige competenties zoals die worden gedefinieerd in het ERK. In het EMTmodel komen die overeen met de subcompetentie Language and Culture (zie figuur 3).

Over de doeltreffendheid van Wikipedia-vertaalactiviteiten voor de activatie van deze competentie in vertalersopleidingen vonden we relevante informatie in de onderzoeken van twee Poolse vertaalspecialisten en didactici, met name Piotr Szymczak en Małgorzata Kodura. Kodura onderzocht de effectiviteit ervan op basis van een Wikipedia-gebaseerde

netwerk. Het EMT-netwerk publiceerde in januari 2009 voor het eerst zijn referentiekader (EMTframework) voor vertaler- en vertaalcompetentie, inclusief het bekende EMT Wheel of Competence die in dit artikel het EMT-model wordt genoemd. Dit is nu een van de belangrijkste referentienormen voor vertaalopleidingen en voor de vertaalcompetentie in de hele Europese Unie en daarbuiten, zowel in academische kringen als in de vertaalwereld (EMT 2017). 
vertaalcursus (t1- en vt-vertalen) die ze gedurende vier semesters in de academiejaren 2017-2018 en 2018-2019 gaf aan het Instituut voor Moderne Talen van de Pedagogische Universiteit in Krakau. De cursus was bedoeld voor masterstudenten in het programma Engelse filologie die drie op Wikipedia geselecteerde artikelen (350-500 woorden) individueel moesten vertalen in kleine groepen van drie tot vier personen. Ze werkten vooral thuis of online met de groep, terwijl tijdens de colleges tijd werd besteed aan het oplossen van technische problemen en het bespreken van toegepaste vertaalstrategieën.

Wat volgens Kodura voor vertaalstudenten in de masteropleiding op taalgebied gunstig is, is dat ze de kans krijgen om hun moedertaal te verbeteren wanneer ze vertalen naar de moedertaal (= t1-vertalen). De studenten die deelnamen aan de op Wikipedia gebaseerde vertaalcursus, hadden volgens Kodura bij het maken van t1-vertalingen echter wel moeilijkheden om de 'droge' Wikipedia-stijl te volgen in hun Poolse vertalingen. Daarom kregen ze eerst de opdracht om Poolse artikelen op taalgebied na te kijken (dit soort specifieke opdrachten wordt door het Poolse Wikipedia-platform aangeboden in een speciale rubriek met opdrachten voor zogenaamde 'nieuwe Wikipedianen'). Op die manier rakten de studenten niet alleen vertrouwd met de Wikipedia-stijl, maar kwamen ze ook voor het eerst in contact met 'Wikipedia-editing' (wat hun de kans bood om hun revisievaardigheden te verbeteren).

Wat de vertaalrichting betreft, werden de studenten naderhand aangemoedigd om Poolse Wikipedia-artikelen over de Poolse geschiedenis, cultuur en gewoonten (gerechten, tradities) in het Engels of de vreemde taal te vertalen (= vt vertalen). Ze werden (en worden) daarna (steeds) door Engelstalige beginnende Wikipedianen aan een taalkundige revisie onderworpen. Volgens Kodura bood dit de studenten de kans om niet alleen hun culturele en transculturele kennis uit te breiden, maar ook om hun Engelse taalvaardigheid te verbeteren en te bevorderen.

Het feit dat door vt-sprekers (= niet-moedertaalsprekers) vertaalde teksten naderhand door t1-sprekers (= moedertaalsprekers) worden nagekeken, maakt Wikipedia-projecten bijzonder geschikt voor internationale samenwerking. Voorbeelden zijn Trans-Atlantic \& Pacific Projects waarin, voor het vertalen en reviseren van teksten, studenten uit het ene land samenwerken met studenten uit een ander land (Maylath et al.). Zulke projecten zouden in de toekomst kunnen worden opgezet tusssen de Poolse 'vertaalstudenten' en Nederlandse of Vlaamse studenten die de teksten zouden reviseren. 
Eerder dan Kodura, onderzocht Szymczak in 2013 de effectiviteit van Wikipedia-activiteiten in de vertalersopleiding. Uit zijn bevindingen kunnen we opmaken dat het niet eenvoudig is te achterhalen of op Wikipedia gebaseerde vertalingen in de vreemde taal (hierna vt-vertalingen) in een cursus voor masterstudenten een doelftreffend hulpmiddel bieden ter bevordering van de kennis van de taal en cultuur van de vreemde taal, alsmede van de algemene of taalspecifieke sociolinguïstische en pragmatische kennis. Szymczak stelt namelijk vast dat de feiten-georiënteerde taal die gebruikt wordt in Wikipedia niet erg geavanceerd is, omdat die vooral beoogt duidelijke informatie te verstrekken. Bijgevolg zouden studenten bij het maken van vtvertalingen vaak onvoldoende uitdaging vinden om nieuwe woorden, idiomen of structuren te leren. Dit argument speelt echter wel in het voordeel van vto-vertaalcolleges voor Poolse masterstudenten neerlandistiek die meestal een halfgevorderd taalniveau hebben bereikt.

Uit dit literatuuronderzoek konden we opmaken dat de vertaalcompetentie van het EMT-model een aantal interessante componenten bevat die gerelateerd zijn aan de bevordering van talige en niet-talige competenties. Het model definieert de vertaalcompetentie namelijk niet alleen als de daadwerkelijke overdracht van betekenissen, maar onderstreept ook het belang van strategische, methodologische en thematische competenties die vereist zijn voor, tijdens en na de zogenaamde 'overdrachtsfase' (EMT 2017, Competence Framework). Wikipedia-gebaseerde opdrachten ondersteunen de ontwikkeling van deze competenties doordat het vertalen van teksten de student aanzet tot een doelgericht zoeken (strategische competentie) naar specifieke bronnen (artikelen, afbeeldingen) over hetzelfde onderwerp met het oog op een adequate overdracht van een brontekst naar een doeltekst waarbij een adequate terminologie, fraseologie en zinsbouw worden gehanteerd.

De toepassing in een vto-vertaalles van activiteiten die bijvoorbeeld gericht zijn op het zoeken naar de juiste woordenschat in domeinspecifieke teksten en de hantering van een adequate stijl in de doelcultuur, zal dus ongetwijfeld de talige en niet-talige kennis en competenties bevorderen, vooral door het feit dat een breder publiek de vertalingen online leest. Bijgevolg zullen de studenten voorzichtiger zijn met bijvoorbeeld hun woordkeuze, wat niet altijd het geval is voor 'klassieke' vertalingen die enkel bestemd zijn voor de docent, en waar het gebruik van een verkeerd woord of een niet-adequate stijl niets meer betekent dan een lager cijfer.

In antwoord op onderzoeksvraag 3 kunnen we in dit voorzonderzoek op basis van deze literatuurstudie besluiten dat Wikipedia-vertaalactiviteiten 
wel degelijk op een doeltreffende manier kunnen worden ingezet in vtovertaalcolleges, zowel voor de bevordering van de talige als van de niettalige competenties van de leerders. Naast een verhoogd intercultureel en cultureel bewustzijn, blijkt namelijk dat Wikipedia-vertaalactiviteiten (waarbij wordt vertaald naar de vreemde taal) in theorie kunnen leiden tot een bevordering van de linguïstische kennis (grammatica, woordenschat, uitdrukkingen) en vaardigheden (schrijfvaardigheid, stijlhantering) in de vreemde taal van masterstudenten met (begin)taalniveau B2.

\section{DIDACTISCHE MEERWAARDE VAN WIKIPEDIA- VERTAALACTIVITEITEN}

In onze zoektocht naar een antwoord op de vierde onderzoeksvraag die betrekking heeft op andere voor- en nadelen van Wikipedia-vertalen en -vertalingen in vertalersopleidingen, vermelden de geraadpleegde docentonderzoekers in de Engelstalige literatuur unaniem de effectiviteit van de zogenaamde 'vertaalinspanning', het innovatieve op het gebied van de vertaaloefeningen in vergelijking met typische vertaaltaken en de tevredenheid van studenten. Die aspecten worden in de hand gewerkt door de mogelijkheid die de leerders krijgen om 1) hun vertalingen aan anderen te laten zien, 2) om hun bijdrage te leveren aan deze alom populaire online-encyclopedie, en 3) om feedback te krijgen van een breder publiek en niet alleen van de docent. Verder wordt gerapporteerd dat Wikipedia-opdrachten de betrokkenheid van studenten bij de vertaalcursus vergroten, door hun de mogelijkheid te geven om aan echte taken te werken, wat in de lijn van Don Kiraly's sociaal constructivistische benadering ${ }^{4}$ zeker een impact heeft op het leerproces.

Szymczak wijst in zijn onderzoek tot slot op een reeks voordelen van dergelijke activiteiten voor de zogenaamde 'sociale dimensie', doordat de leerder zich ervan bewust is dat hij iets doet wat nuttig is voor anderen (Szymczak 65).

Een ander voordeel van Wikipedia-vertalen is het feit dat de leerder de nodige links in zijn digitale vertalingen moet aanbrengen en bijvoorbeeld in de huid van de lezer moet kruipen om te achterhalen welke termen of uit-

\footnotetext{
${ }^{4}$ Het sociaal constructivisme is een leerfilosofie die het leren beschouwt als een sociaal en collaboratief proces waarbij de leerders - elke met hun eigen idiosyncratische behoeften en achtergronden - hun kennis opbouwen via de interactie met 'medeleerders' en docent en via de taken zelf (Lantolf).
} 
drukkingen uit de broncultuur meer uitleg vergen in de doelcultuur. Hierdoor wordt de vaardigheid in het bemiddelen (mediation) van de leerder gestimuleerd. Dit is precies een van de vaardigheden die door het ERK als leerdoel wordt vooropgesteld in het kader van zogenaamde bemiddelingsactiviteiten of vertalen (ERK 2008, 147). Het werken aan vertalingen binnen een digitale ruimte als Wikipedia zal er bovendien voor zorgen dat de leerders hun technologische vaardigheden ontwikkelen (zoals hantering van vertaaltechnologie, zoekmachines, CAT-tools en MT-systemen, verwerking en beheer van bestanden in verschillende formaten). Tot slot zullen studenten via het virtueel online platform leren samenwerken met anderen en resultaten en feedback online leren delen.

Wat de nadelen betreft, zal volgens ons vooral rekening moeten worden gehouden met het tijdsverlies omwille van de noodzaak om uitleg te geven over de technische aspecten van Wikipedia. Verder zullen we ook voor ogen moeten houden dat het vast niet altijd haalbaar zal zijn om teksten te publiceren die door studenten worden vertaald. In ieder geval zal het 'experimenteren in de zandbak' alvast een meerwaarde hebben voor de activatie van de talige en niet-talige competenties van de vreemdetaalleerder die in dit artikel werden gepresenteerd.

\section{CONCLUSIE}

Dankzij het onderhavige onderzoek waarin we naar het nut en de voordelen van Wikipedia en Wikipedia-vertalingen voor het vto in een universitaire filologische masteropleiding (taalniveau B2) hebben gepeild, hebben we in de eerste plaats ontdekt dat de competenties die van essentieel belang zijn in het vto, met name de interculturele en de communicatieve competenties, er in theorie wel degelijk mee bevorderd kunnen worden. Dit wordt bevestigd door de bevindingen van het praktische onderzoek in vertalersopleidingen waaruit blijkt dat deze competenties, die een onderdeel vormen van de vertaalcompetentie, wel degelijk gestimuleerd worden wanneer leerders werken met Wikipedia-vertaalopdrachten binnen de Wikipediaruimte. Uit het onderzoek kunnen we tevens afleiden dat een Wikipediavertaalcursus in het vto een aantal voordelen heeft. Hierbij denken we in de eerste plaats aan de vanzelfsprekende functionaliteit van de werkmethode, en aan de motivatie van de leerder die in de hand wordt gewerkt, omdat hij de kans krijgt om een vertaald artikel van zijn keuze online te publiceren. Tot 
slot bieden Wikipedia-activiteiten hem de kans om als bemiddelaar op te treden die - waar nodig - extra informatie aanbiedt aan de lezers van de doelcultuur. Wat de nadelen betreft, zullen we vooral rekening moeten houden met het eventuele tijdverlies dat verband houdt met het technisch aspect (online werken binnen de Wikipedia-ruimte).

Uit de bevindingen van dit literatuuronderzoek blijkt in ieder geval het belang van een uitgebreider, praktisch onderzoek naar de doeltreffendheid van Wikipedia-vertalen en -vertalingen in vto-vertaalcolleges, meer bepaald in de masteropleiding neerlandistiek aan de Katholieke Johannes Paulus II universiteit Lublin in Polen.

\section{BIBLIOGRAFIE}

Al-Shehari, Khaled. "Collaborative learning: trainee translators tasked to translate Wikipedia entries from English into Arabic." The Interpreter and Translator Trainer, 11, 2017, no. 4, pp. 357-372.

Alonso, Elisa, en Elisa Calvo. "Developing a blueprint for a technology-mediated approach to translation studies." Meta, 60, 2015, no. 1, pp. 135-157. Doi.org/10.7202/1032403a.

Howatt, Anthony Philip Reid. A History of English Language Teaching. Oxford University Press, 1984.

Kodura, Małgorzata. "Wikipedia-Based Activities and Translation Competence Development." Current Trends in Translation Teaching and Learning E, no. 6, 2019, pp. 193-231.

Lantolf, James P. Sociocultural Theory and Second Language Learning. Oxford University Press, 2000.

Maylath, Bruce, Sonia Vandepitte en Birthe Mousten. "Growing grassroots partnerships." Designing Globally Networked Learning Environments: Visionary Partnerships, Policies, and Pedagogies, bewerkt door Doreen Starke-Meyerring and Melanie Wilson, Educational Futures: Rethinking Theory and Practice, Vol. 20. Brill, 2008, pp. 52-66.

Szymczak, Piotr. "Translating Wikipedia Articles: A Preliminary Report on Authentic Translation Projects in Formal Translator Training." Acta Philologica 44, 2013, pp. 6-70.

Waterlot, Muriel. Functionele \& Taakgerichte Vertaaldidactiek in het Universitaire Vreemdetalenonderwijs. Wydawnictwo KUL, 2018.

\section{GERAADPLEEGDE WEBSITE}

Taalunieversum:

taalunieversum.org/onderwijs/termen/term/237/nvt/ (geraadpleegd op 20.05.2017)

taalunieversum.org/sites/tuv/files/downloads/gemeenschappelijk_europees_referentiekade r.pdf. Geraadpleegd op 10.2019 .

EMT competence framework (2017):

ec.europa.eu/info/sites/info/files/emt_competence_fwk_2017_en_web.pdf. Geraadpleegd op 10.2019 .

Wikipedia-Zandbak nl.wikipedia.org/wiki/Wikipedia:Zandbak/hoofding. Geraadpleegd op 10.2019. 


\section{TŁUMACZENIE W NAUCZANIU JĘZYKÓW OBCYCH: WIKIPEDIA JAKO NARZĘDZIE DYDAKTYCZNE?}

\section{Streszczenie}

Niniejszy artykuł jest usytuowany w obszarze dydaktyki nauczania języków obcych i przedstawia wyniki wstępnego badania przeprowadzonego w celu określenia stopnia, w jakim Wikipedia może być wykorzystywana jako pomoc dydaktyczna i narzędzie do nauki w zajęciach translatorskich L2 w nauczania języków obcych na studiach magisterskich na Katolickim Uniwersytecie Lubelskim Jana Pawła II. Ze względu na, z jednej strony, swobodny dostęp do tej internetowej encyklopedii, z drugiej zaś bogactwo tekstów (w języku polskim i niderlandzkim), zawierających treści kulturowe, zbadaliśmy, w jakim stopniu thumaczenie Wikipedii może być z powodzeniem wykorzystywane jako narzędzie w zajęciach z przekładu L2. Rosnące znaczenie narzędzi technologicznych (takich jak słowniki elektroniczne, terminologiczne bazy danych i oprogramowanie do thumaczenia maszynowego) dla tłumaczeń i ich wykorzystania w nauczaniu języków obcych z jednej strony, a także fakt, że polscy absolwenci filologii niderlandzkiej często pracują jako thumacze $\mathrm{z}$ drugiej strony, stanowiły punkt wyjścia dla tych badań, które zostały przeprowadzone jako wstępna faza (studium przypadku) szerszych badań nad praktycznym zastosowaniem działań tłumaczeniowych Wikipedii na lekcjach akwizycji języka.

Słowa kluczowe: tłumaczenie; Wikipedia; nauczanie języków obcych; dydaktyka przekładu; dydaktyka; glottodydaktyka.

\section{TRANSLATING IN THE TEACHING OF FOREIGN LANGUAGES: WIKIPEDIA AS A DIDACTIC TOOL?}

\section{S u m m a r y}

This article relates to the field of the didactics of foreign language teaching, and presents the results of a preliminary study carried out in order to determine the extent to which Wikipedia can be used as a didactic aid and learning tool in the translation lectures of foreign language teaching in the Master's degree in Dutch at the John Paul II Catholic University of Lublin (Poland). In view of the free access to this online encyclopedia, on the one hand, and the richness of texts (in Polish and Dutch) with a cultural content on the other, we investigated to what extent Wikipedia translation can be successfully used as a tool in L2 translation classes. The increasing importance of technological tools (such as electronic dictionaries, terminological databases, and machine translation software) for translation and its use in language teaching, on the one hand, and, on the other, the fact that Polish graduates in Dutch philology often work as translators, were the starting point for this research, which was conducted as a preliminary phase (case study) of a more extensive study into the practical application of Wikipedia translation activities in language acquisition classes.

Keywords: translation; Wikipedia; Foreign Language Education (FLE); translation didactics; foreign language teaching; language teaching. 